KENOSIS : JURNAL KAJIAN TEOLOGI

ISSN 2460-6901(Print), 2656-4483 (Online)

https://e-journal.iaknambon.ac.id/index.php/KNS

DOI: 10.37196/kenosis.v7i2.355

\title{
EMDE, COOLEN, DAN ISTRINYA: \\ Analisis Gender dan Relasi Kuasa dalam Pekabaran Injil di Jawa Timur
}

(1812-1848)

\section{Maria Theofani Widayat}

Sekolah Tinggi Filsafat Theologi Jakarta

Jl. Proklamasi No.27, RT.11/RW.2, Pegangsaan,

Kec. Menteng, Kota Jakarta Pusat, DKI Jakarta 10320

mariawidayat@gmail.com

\begin{abstract}
This article aims to build awareness of the gender equality issues in the history of Christianity through historical research. The subject of the research is the history of missions in East Java, especially in 1812-1848. Therefore, this study employs an analysis of gender and power relations both through feminist theory initiated by Kwok Pui Lan and also orientalism theory brought by Edward Said in examining the history of mission in East Java on that period. The characters appointed as the research subjects are Johannes Emde and Coenrad Laurens Coolen, along with their wives and children. They are the pioneers in introducing the gospel to the Javanese in East Java, thus become the foundations of the Christian community in East Java. In particular, the life of Emde and Coolen are so intertwined with the history of the East Java Christian Church (GKJW). However, there is a gender gap found in the mission by Emde and Coolen. In response, this research is conducted to keep building the awareness of gender justice as the history of Christianity carry on.
\end{abstract}

Keywords: Mission, Women, Power relation, History.

\begin{abstract}
Abstrak
Tulisan ini adalah bentuk upaya membangun kesadaran terhadap keadilan gender atas sejarah Kekristenan melalui penelitian pada sejarah pekabaran Injil di Jawa Timur khususnya pada tahun 1812-1848. Untuk itu penelitian ini menggunakan analisis gender dan relasi kuasa melalui teori feminis yang digagas oleh Kwok Pui Lan dan teori orientalisme yang dibawa oleh Edward Said dalam menelaah sejarah pekabaran Injil di Jawa Timur pada periode tersebut. Tokoh-tokoh yang diangkat adalah Johannes Emde dan Coenrad Laurens Coolen, beserta istri dan anaknya. Mereka memiliki andil besar dalam mengenalkan Injil dan menjadi pondasi
\end{abstract}


komunitas Kristen di Jawa Timur. Utamanya tokoh Emde dan Coolen yang begitu melekat pada sejarah Greja Kristen Jawi Wetan (GKJW). Namun dalam proses pekabaran Injil yang dilakukan oleh Emde dan Coolen lekat dengan ketimpangan gender. Oleh karena itu, penelitian ini dilakukan supaya terus terbangun kesadaran pada keadilan gender dalam membaca dan melanjutkan sejarah Kekristenan di mana saja.

Kata kunci: Pekabaran Injil, Perempuan, Relasi kuasa, Sejarah.

\section{PENDAHULUAN}

Hadirnya agama Kristen di tanah Jawa tidak terlepas dari berbagai polemik. Begitu pula dalam sejarah pekabaran Injil di Jawa Timur sebagai cikal bakal berdirinya Greja Kristen Jawi Wetan (GKJW). Pada penulisan sejarah pekabaran Injil di Jawa Timur, subyek pemberitaan sejarah adalah laki-laki. Ada dua tokoh laki-laki yang menjadi sorotan pemberitaan sejarah pekabaran Injil di Jawa Timur. Johannes Emde, yang menetap di Surabaya dan menikah dengan seorang perempuan Jawa dan memiliki anak perempuan. Tokoh lain selain Emde adalah Coenrad Laurens Coolen, seorang keturunan Indo Eropa. Ia dididik oleh ibunya yang seorang Jawa dengan cara Jawa, sehingga ia lebih dekat dengan budaya Jawa. Coolen menikah dua kali. Pertama dengan seorang perempuan Eropa, kedua dengan seorang perempuan Jawa. Sepanjang sejarah pekabaran Injil di Jawa Timur, kedua tokoh di atas cukup sentral dengan kiprahnya memberitakan Injil bagi orang-orang Jawa. Hingga saat ini ketika berbicara tentang sejarah GKJW selalu lekat dimulai dengan peran dan jasa kedua tokoh tersebut. Peran perempuan di dalamnya hampir selalu tidak pernah dibahas, bahkan pada beberapa buku sejarah hanya disebut sepintas lalu saja. Ini mengindikasikan adanya konstruksi sejarah yang timpang.

Tahun 1812 hingga 1816, wilayah Hindia-Belanda berada di bawah kekuasaan Inggris yang dipimpin oleh Thomas Stamford Raflles. Beberapa kebijakan Raflles di antaranya yaitu menghentikan perdagangan budak, mereformasi sistem pertanahan dengan menggunakan sistem sewa tanah, karena tanah dianggap milik pemerintah. Ini juga didukung oleh pemahaman Jawa kuno, bahwa semua tanah adalah milik raja. Jadi setiap petani harus membayar pajak dalam bentuk uang atau beras sesuai dengan luas tanah yang disewa. Raflles selama memerintah meneruskan kebijakan kebebasan 
beragama. Hal tersebut berdampak pada semakin tersebarnya agama Kristen di wilayah Hindia-Belanda. Atas anjuran Raffles, pada tahun 1813 untuk pertama kali Lembaga Pekabar Injil Belanda atau Nederlansch Zendelinggenotschap (NZG) mengutus tiga orang Pekabar Injil /zendeling masuk ke Pulau Jawa. ${ }^{1}$ Tiga zendeling yang diutus ke Hindia-Belanda oleh NZG adalah Joseph Kam, J.C.Supper, dan G.Bruckner. $^{2}$ Setelah tahun 1816 Nusantara kembali berada di bawah kekuasaan kolonial Hindia-Belanda. Pada saat berada di bawah kekuasaan kolonial Belanda, sempat dikeluarkan aturan larangan mengabarkan Injil pada orang-orang Jawa yang dianggap beragama Islam untuk mengurangi pemberontakan pada kolonial HindiaBelanda. Di samping itu, kehidupan rakyat dipengaruhi oleh cara hidup dan aturan kolonial yang patriarki dalam berbagai bidang. Kolonial juga membuat aturan hingga urusan rumah tangga yang meniru cara hidup orang Kristen di Eropa, seperti pernikahan harus monogami, rumah tangga dikepalai oleh laki-laki, perceraian dilarang, bahkan pernikahan harus dengan orang Kristen. Kehadiran otoritas Kristen maupun misionaris atau zendeling mempertajam hierarki gender. Mereka tidak terlalu memperhatikan eksistensi perempuan, dan cenderung merendahkan potensi perempuan. ${ }^{3}$ Dalam kehidupan orang-orang Eropa, perempuan sering kali dipandang rendah. Apalagi ketika orang-orang berdarah Eropa menguasai Jawa, maka para perempuan Jawa mendapat tekanan yang lebih besar.

Hal ini akan diteliti dengan menggunakan analisis gender dan relasi kuasa untuk melihat lebih luas eksistensi perempuan dalam sejarah pekabaran Injil di Jawa Timur pada tahun 1812-1848. Tahun 1812-1848 digunakan untuk menjadi batasan penelitian. Penulis melihat selama ini belum ada penelitian yang secara khusus membahas sejarah pekabaran Injil di Jawa Timur dengan menggunakan perspektif analisis gender dan relasi kuasa. Penelitian inidiharapkan dapat memantik kesadaran akan eksistensi perempuan dalam sejarah pekabaran Injil di Jawa Timur. Dengan demikian, perempuan dan laki-laki dapat menjadi subyek historis sesuai dengan realitas yang terjadi dalam sejarah pekabaran Injil di Jawa Timur, khususnya pada tahun 1812-1848, sehingga pembacaan terhadap sejarah pekabaran Injil di Jawa Timur dapat lebih utuh. 


\section{METODE PENELITIAN}

Tulisan ini menggunakan metode penelitian kualitatif, khususnya metode analisis dokumen atau analisis isi. Penelitian ini menganalisis pustaka sejarah dari beberapa literatur tentang sejarah pekabaran Injil di Jawa Timur pada tahun 18121848 dengan menggunakan lensa analisis gender dan relasi kuasa, melalui teori feminisme yang ditawarkan oleh Kwok Pui-Lan dan teori orientalisme yang dibawakan oleh Edward Said. Penelitian ini dilakukan untuk mengetahui makna, kedudukan dan hubungan antara Emde, Coolen, dan istrinya yang menjadi pemberitaan sejarah awal mula pekabaran Injil di Jawa Timur. Selanjutnya untuk mengetahui manfaat, hasil atau dampak dari hal-hal tersebut. Harapannya melalui penelitian ini dapat memberi pandangan dan pemahaman baru tentang perempuan secara eksplisit maupun implisit

\section{HASIL DAN PEMBAHASAN}

\section{Konsep Analisis Gender \& Relasi Kuasa}

Gender merupakan sifat yang ada pada laki-laki dan perempuan, berdasarkan pada kualitas, kemampuan, peran, dan fungsi, sebagai hasil dari produk sosiokultural dan sejarah. Berbicara tentang analisis gender, tidak berarti hanya berbicara tentang hubungan sosial antara laki-laki dan perempuan, melainkan juga tentang relasi kuasa dalam kehidupan sosial secara mendasar. Untuk itu perlu mencari bukti empiris, mempelajari, membangun kesadaran dan mengusahakan perubahan terhadap kemungkinan-kemungkinan ketidakadilan gender, seperti alienasi, eksploitasi, dan pembungkaman pada kesadaran akan potensi-potensi dalam kehidupan sehari-hari. ${ }^{4}$ Di samping itu, perempuan dan laki-laki rawan mengalami dehumanisasi, yakni ketika laki-laki atau perempuan mengalami ketidakadilan gender atau justru tanpa disadari melanggengkan penindasan. Hal tersebut dikuatkan dengan sistem patriarki. Kemudian, perempuan ditempatkan pada urusan domestik, sedangkan laki-laki pada urusan publik. Perempuan dilekatkan pada urusan reproduktif, laki-laki pada urusan produktif. Inilah yang menyebabkan ketimpangan pada relasi gender, yang bias pada kepentingan laki-laki. ${ }^{5}$

Pada budaya Jawa, patriarki tampak salah satunya pada istilah yang disematkan pada perempuan, misalnya kanca wingking yang berarti teman untuk 
urusan-urusan belakang. Istilah itu menempatkan perempuan lebih rendah dari lakilaki. Di samping itu, gambaran tentang perempuan yang ideal adalah perempuan yang lemah lembut, manut atau patuh dan tunduk, tahu diri dalam arti tidak melebihi lakilaki, mendukung karir suami, dan ibu yang mrantasi atau dapat mengatasi semua urusan "rumah". Sedangkan gambaran laki-laki ideal adalah serba tahu, panutan, lebih dari perempuan, pemimpin. ${ }^{6}$ Dalam masyarakat Jawa, pandangan tersebut diterima begitu saja dan umum menjadi alat untuk menilai kehidupan laki-laki dan perempuan. Untuk itulah, analisis gender dan relasi kuasa digunakan untuk menyoroti ketidakadilan gender dalam berbagai segi kehidupan, sehingga dapat terbangun kesadaran pada kondisi ketidakadilan gender di mana saja.

\section{Perspektif Feminis \& Orientalisme}

Kwok Pui Lan menyatakan bahwa penting untuk memulihkan kembali perempuan sebagai subyek historis ${ }^{7}$ meski tantangannya ialah menghadapi marginalisasi multidimensi yang erat kaitannya dengan dampak kolonialisme. Dengan menempatkan kembali perempuan sebagai subyek historis berarti memberi tempat bagi perempuan untuk mengartikulasikan pengalaman hidupnya yang selama ini lebih sering digambarkan oleh pihak lain ${ }^{8}$. Oleh karena itu, perempuan harus mempertanyakan kembali narasi sejarah yang dibentuk oleh pihak lain termasuk para penjajah $^{9}$. Meski tidak mudah juga bagi perempuan untuk mengartikulasikan sejarah hidupnya, karena banyak di antara para perempuan Asia yang tidak diizinkan untuk berpartisipasi dalam menceritakan kembali atau membentuk kembali masa lalunya. Maka yang menjadi hal mendesak adalah memberi perhatian pada sejarah secara utuh, sehingga ada kesempatan bagi perempuan untuk mengartikulasikan kembali ingatan tentang pengalaman kehidupannya bagi masa kini dan masa depan ${ }^{10}$.

Pada masa pascakolonial, perempuan Asia dianggap tidak cukup otentik, ketika pada saat yang sama mereka dianggap tidak cukup Barat ${ }^{11}$. Edward Said menunjukkan konsep "Barat" dan "Timur" dalam orientalisme", yaitu tentang bagaimana "Barat" mendekati dan memperlakukan "Timur". "Barat" disematkan bagi yang memiliki kekuatan, sedangkan "Timur" mencerminkan yang lemah. Menurut Said hal tersebut justru membuat semakin terpolarisasi, di mana "Timur" semakin "Timur" dan“Barat" semakin "Barat". Tanpa disadari membuat pemikiran manusia 
menjadi terkotak-kotak antara "Timur" dan "Barat". Ironisnya, ini diterima begitu saja sebagai suatu kebenaran. ${ }^{13}$ Orientalisme merupakan representasi yang dibuat untuk menggambarkan "Timur". Padahal "Timur" yang direpresentasikan bukanlah “Timur" sebagaimana adanya melainkan sebagaimana seharusnya ${ }^{14}$. Hal tersebut mendorong meningkatnya rasa superioritas tertentu dan sering kali sikap "Barat" terhadap "Timur" selalu paternalistik dan arogan. ${ }^{15}$ Melanjutkan pembicaraan tentang konteks perempuan di Asia di atas, dapat dikatakan bahwa "Timur" digunakan untuk menunjuk pada Asia, khususnya pada para perempuan yang dipandang sebagai yang lemah.

Perjuangan perempuan untuk mendapatkan kemerdekaan secara sistematis cukup rumit, karena dibungkam oleh kekerasan domestik, perkosaan, kecaman publik, pemenjaraan, dan penyiksaan. Hal ini tampak pada sistem keluarga patriakal, di mana pada saat belum menikah, perempuan adalah milik ayahnya, dan saat sudah menikah, suamilah yang memiliki perempuan sebagai istrinya. Pada gereja dan organisasi keagamaan, etos kebudayaan, dan aturan pemerintah saling mendukung dan menjaga perempuan tetap submisif dan berada di tempatnya. ${ }^{16}$ Apalagi di Asia, perempuan diharapkan selalu patuh termasuk ketika berada di gereja. Ini tidak terlepas dari cara pandang yang misoginis pada tradisi kristen. Ajaran-ajaran misoginis dalam tradisi kristen maupun dalam adat istiadat menolak para wanita kesempatan yang setara untuk melayani dan memimpin. Contohnya pendeta perempuan sering diasosiasikan hanya pada pelayanan rumah, mengunjungi orang sakit dan tanggung jawab pada persekutuan wanita dan anak-anak. Pendeta perempuan yang menikah sering dipertanyakan integritas dan tanggung jawabnya antara berada di tempat pelayanan atau mengurus keluarga. Sedangkan pendeta perempuan yang belum menikah sering dicurigai atau justru dipandang kasihan.

Pui-Lan menggagas imajinasi pascakolonial dengan semangat untuk melepaskan diri dari segala bentuk sindrom kolonial melalui berbagai proses. Ia berusaha membangun diskursus analisa atas wacana pascakolonial dalam horizon pengetahuan yang didominasi oleh Barat, analisa ketergantungan antara bekas jajahan dengan penjajah, dan bagaimana sistem pengetahuan yang dibangun oleh penjajah berdampak bagi orang-orang yang dijajah bahkan saat sudah lama ditinggalkan oleh para penjajah. ${ }^{17}$ Di samping itu, Pui Lan juga memperhatikan bagaimana interpretasi 
dilakukan terhadap Alkitab yang ditempatkan secara utuh dengan memperhatikan sejarah teks tersebut. Alkitab merupakan teks yang ditulis dan dikumpulkan dengan latar belakang politis tertentu oleh kaum elit kolonial laki-laki untuk ditulis kembali dengan berdamai dalam sejarah dalam konotasi identitas individu maupun kolektif pada sebuah era kekuasaan tertentu. Untuk itu, diperlukan kepekaan pada kontrol patriakal dalam berbagai bidang di mana kaum elit kolonial dapat memegang kendali. $^{18}$

Pui-Lan menawarkan cara baca teks dengan historis imajinatif. Kita diajak untuk melihat kembali ke belakang dan mengklarifikasi beberapa isu, khususnya berkaitan dengan subjektivitas perempuan yang secara historis tidak dianggap bernilai. Sebagaimana pendapat Fiorenza yang diangkat oleh Pui-Lan, menunjukkan bahwa penulisan sejarah hanyalah retoris semata, sangat politis dan tidak netral. ${ }^{19}$ Oleh karena itu, perlu menggali memori, memperhatikan dan mencari catatan-catatan harian, dokumenter, karya-karya sastra dll. Tujuannya adalah melacak kembali sejarah yang tidak tersuarakan. Sejarah para perempuan ataupun orang-orang yang termarjinalkan lainnya. Pui-Lan mengingatkan bahwa yang menulis sejarah 'kita', perempuan Asia, Kristen Asia, adalah misionaris Barat ${ }^{20}$ dengan cara pandang Barat yang dilekatkan pada sejarah Asia, yang mana bisa jadi berbeda dengan sejarah 'kita' sendiri.

\section{Sejarah Pekabaran Injil di Jawa Timur Pada 1812-1848}

Pada masa kolonial Hindia-Belanda, terdapat Gereja Protestan HindiaBelanda. Gereja tersebut didirikan oleh kolonial Hindia-Belanda untuk melayani orang-orang Kristen Eropa di wilayah Hindia-Belanda. Gereja Protestan Hindia Belanda di Jawa Timur saat itu hanya berada di Surabaya dengan anggota orang-orang Eropa, Indo Eropa, dan beberapa orang Ambon. Gereja ini tidak pernah melakukan pekerjaan mengabarkan Injil di kalangan orang-orang Jawa. ${ }^{21}$ Kemudian pekabaran Injil pada orang-orang Jawa di Jawa Timur diawali dan dilakukan oleh Johannes Emde, salah seorang anggota jemaat Gereja Protestan Hindia Belanda di Surabaya, dan Coenrad Laurens Coolen, seorang Indo-Eropa yang membuka hutan di wilayah Ngoro, Jawa Timur. 
Johannes Emde ${ }^{22}$ adalah seorang kelasi kapal asal Waldeck, Jerman, yang pergi ke Hindia-Belanda untuk menyaksikan sebuah negara yang tidak memiliki musim dingin. Setibanya di Batavia ia tidak memiliki pekerjaan, sehingga pemerintah Hindia-Belanda mengharuskan Emde masuk dalam dinas ketentaraan dan bergabung dalam peperangan melawan suku-suku di Kalimantan. Setelah keluar dari ketentaraan, Emde menetap di Surabaya dan menjadi tukang arloji. Pada saat itu, status sosial dan ekonomi Emde tergolong rendah sehingga tidak memungkinkan untuk menikahi perempuan Eropa. Oleh karena itu, ia memutuskan untuk menikahi perempuan Jawa, anak dari seorang kepala distrik. Setelah perempuan Jawa itu menjadi Kristen, ia diberi nama Barat yaitu Amarentia Manuel. Mereka memiliki anak perempuan dan diberi nama Johanna Wilhelmina Emde. ${ }^{23}$

Emde memiliki hasrat untuk mengabarkan Injil bagi orang-orang Jawa. Namun terhalang oleh peraturan yang dikeluarkan pemerintah Hindia-Belanda yang melarang pekabaran Injil kepada masyarakat Jawa yang bergama Islam. Emde pun sempat ditahan dua kali karena usahanya mengabarkan Injil. Disamping itu, Emde memiliki keterbatasan dalam menggunakan bahasa Jawa. Dalam hal ini, istrinya banyak mendukung dan membantunya dengan menuliskan selebaran-selebaran dalam bahasa Jawa dan menuliskan uraian makna Injil Yesus Kristus. Putrinya disuruh berkeliling kota dan membawa buku-buku bacaan untuk dijual kepada orang Belanda dan Indo Belanda, serta membawa selebaran berbahasa Jawa tadi untuk dibagikan pada orang Jawa yang sekiranya bisa membaca. ${ }^{24}$

Pada suatu hari, seorang modin yang tinggal di desa Wiyung bernama pak Dasimah, mendapat sebuah buku dari seorang pemudi Belanda saat ia sedang berjualan sarung keris di pasar hewan Wonokromo Surabaya. Pak Dasimah tidak bisa membaca, tetapi pemudi itu mendesaknya untuk menerima buku tersebut. Ketika pak Dasimah berkumpul dengan teman-temannya di Musala, ia dan teman-temannya mulai membuka buku itu dan ketika dibacakan, ia terkejut sebab diawali dengan tulisan Ewangelion saking Yesus Kristus Putrane Allah. Bagi umat Islam, hal itu aneh sebab Allah memiliki putra. Meski tidak tahu maksudnya, namun mereka sering mendiskusikannya. Tampaknya itu adalah penggalan terjemahan dari Injil Markus. ${ }^{25}$

Hingga suatu waktu anak pak Dasimah menjual rumput di Surabaya dan kebetulan Emde membeli rumput pada anak tersebut. Anak pak Dasimah membawa 
rumput ke belakang rumah Emde. Saat melewati rumah Emde, anak pak Dasimah melihat gambar di dinding yang mirip dengan gambar yang ada dalam Injil Markus, buku yang diperoleh pak Dasimah dari pemudi Belanda waktu itu. Anak pak Dasimah kemudian menanyakan tentang gambar itu pada pelayan rumah. Pelayan rumah meneruskan pertanyaan itu pada istri Emde. Dengan senang hati istri Emde menceritakan tentang gambar tersebut. ${ }^{26}$

Kebanyakan orang-orang yang terpengaruh dengan pekabaran Injil saat itu adalah orang-orang Jawa yang bekerja sebagai pelayan di rumah orang-orang Belanda. Dapat dikatakan jangkauannya tidak luas dan bukan pada orang-orang penting dari masyarakat Jawa. Bila ada orang yang ingin belajar ajaran Kekristenan lebih lanjut, Emde menyerahkan pada pendeta Gereja Protestan Hindia-Belanda yang ada di Surabaya. Mereka akan diberi pendidikan agama Kristen, lalu dibaptis, dan masuk dalam Gereja Protestan Hindia-Belanda yang ada di Surabaya. Menurut Emde, orang-orang Jawa yang menjadi Kristen harus meninggalkan seluruh adat dan kebiasaannya. Rambut orang-orang Kristen Jawa digunting, dan pakaiannya diganti dengan celana dan baju. Dengan kata lain, orang Jawa yang menjadi Kristen masuk menjadi orang Eropa. ${ }^{27}$ Cara pandang dan apa yang dilakukan oleh Emde dalam menyebarkan Injil sangat berbeda dengan yang dilakukan oleh Coolen.

Coenrad Laurens Coolen ${ }^{28}$ adalah seorang Indo Eropa. Ayahnya berasal dari Rusia dan ibunya adalah seorang Jawa keturunan ningrat dari Kasunanan Surakarta. Ia lahir di Ungaran pada tahun 1773 dan meninggal di Ngoro pada tahun $1873^{29}$. Pada masa mudanya, Coolen tinggal di Semarang. Ia adalah seorang yang pandai menggambar saat bersekolah di sekolah rendah Eropa. Ia kemudian menjadi juru gambar pada Dinas Pemetaan untuk pemugaran reruntuhan candi-candi Hindu Jawa, dan selama tiga setengah tahun berkeliling menjelajahi Jawa Timur. Coolen banyak mendapatkan pengaruh dan didikan dalam lingkungan orang-orang Jawa. Sejak muda Coolen sudah terbiasa dengan ajaran ngelmu Jawa. Saat Coolen menjadi serdadu artileri di Surabaya, ia menikah dan memiliki anak ${ }^{30}$. Namun ia merasa tidak bahagia, karena saat Coolen meminta pindah ke Mojoagung untuk bekerja menjadi pengawas hutan jati Gubernemen, istri dan anak-anaknya tinggal di Surabaya. Ketika ia tinggal di Mojoagung, Coolen menikahi seorang wanita Jawa, yang adalah pembantu rumah 
tangganya. Perempuan itu bernama Sadijah, kemudian mereka memiliki enam orang anak. $^{31}$

Coolen kemudian membuka tanah pertanian karena merasa penghasilannya tidak mencukupi. Ia mendapat surat izin dari Gubernemen tertanggal 3 Juli 1827 untuk membuka lahan menjadi tempat menanam padi dan palawija selama 30 tahun di Ngoro. Kemudian Coolen bersama anak-anaknya dengan Sadijah dan beberapa orang pindah ke Ngoro. Mereka menebang pohon, mencangkul tanah, menyiapkan persawahan, membuat pemukiman kecil serta mendirikan pondok bambu. Singkatnya, setelah hutan di Ngoro berubah menjadi lahan pertanian, makin banyak orang datang ke sana dan menggabungkan diri dengan Coolen. Semua orang disambut baik oleh Coolen, diizinkan untuk memberi makan sapi-sapi bajaknya sebagai ganti tenaga mereka mengolah tanah. Bukan hanya para petani, ada juga buronan polisi yang kabur dan bersembunyi di wilayah pertanian itu. Mereka tetap diterima oleh Coolen dengan syarat untuk hidup baik dan ikut bekerja di lahan pertanian tersebut. Coolen menjaga dan merawat tempat itu dengan baik. Ia berjaga atau meronda setiap malam, ia mengawasi pekerjaan dengan baik, sehingga hasil panen memuaskan bahkan dapat disimpan dalam lumbung, dan dibagi-bagikan pada saat terjadi paceklik. Bukan hanya mengawasi pekerjaan saja, Coolen selalu membajak dan meluku tanahnya lebih dulu sebelum dilanjutkan oleh orang-orang yang tinggal dan bekerja di sana. Sambil membajak Coolen menyanyikan sebuah permohonan berkat dengan tembang Jawa ciptaan Coolen sendiri. Nyanyian ini mengandung harapan supaya Tuhan memberkati hasil pertanian di sana. Makin hari, Coolen kemudian mulai memperkenalkan agama Kristen pada penduduk di pertaniannya sekitar tahun 1835 hingga $1852 .^{32}$

Coolen menyebarkan Injil dengan cara dan pendekatan yang lekat dengan kehidupan masyarakat Jawa. Kebanyakan menggunakan tembang dan rapalan, misalanya pengakuan Iman Rasuli digubah dalam bahasa Jawa dengan nama Rapal Pangandel atau dasa titah yang digubah menjadi Racikan Sedasa Perkawis ${ }^{33}$. Apabila ada orang yang telah menetapkan hatinya untuk menjadi Kristen, maka Coolen menetapkan syarat wajib untuk mengucapkan pengakuan Iman Rasuli dan Doa Bapa Kami. Bagi Coolen, baptisan bukan syarat mutlak. Coolen memandang bahwa dengan baptisan, orang Jawa dapat kehilangan identitas keJawaannya dan menjadi sama dengan orang Belanda. 


\section{Analisis Gender dan Relasi Kuasa terhadap Emde dan istrinya dalam pekabaran Injil di Jawa Timur}

Johannes Emde merupakan salah satu tokoh sentral dalam sejarah pekabaran Injil di Jawa Timur, khususnya bagi Greja Kristen Jawi Wetan (GKJW). Pandangannya terhadap kehidupan orang Kristen yang ideal, penghayatan terhadap iman Kristen, hingga pemahamannya tentang baptisan diikuti dan sedikit banyak merasuk dalam kehidupan GKJW. Pekabaran Injil yang dilakukan oleh Emde tidak sekedar menceritakan tentang isi Injil, melainkan juga mengajarkan tentang cara hidup saleh, termasuk perjuangan dalam melawan pergundikan ${ }^{34}$ yang umum terjadi masa itu. Kiprah Emde yang menjadi sorotan dalam sejarah pekabaran Injil di Jawa Timur tidak dikerjakannya sendiri. Ada istri dan anaknya yang ikut terlibat di dalamnya. Hal tersebut ditunjukkan dari beberapa literatur berikut ini.

Pertama, pada dalam buku berjudul Tumbuh Berkembang dan Bertanggung jawab karya Nortier, seorang pendeta zending yang bekerja di Jawa Timur sejak 1915, dan menjadi guru di sekolah teologi Bale Wiyata, Malang ${ }^{35}$, tentang Emde tertulis demikian: "Oleh perkawinannya dengan nona Amarentia Manuel ia (Emde) menjadi tokoh terkenal, disayangi orang-orang Indo Eropa dan mendapat tempat di hatinya, akan tetapi kurang dihargai orang-orang Eropa, oleh karena ia kerap kali mencela sikap sombong mereka terhadap orang Jawa dan Indo Eropa." Selanjutnya, ia menuliskan: "Sejak istri Emde berpindah agama dan menjadi Kristen, ia dengan rajinnya berusaha menyebarkan Injil. Ditulisnya selebaran-selebaran dalam bahasa Jawa, dan di situ diuraikannya makna Injil Yesus Kristus. "36

Kedua, pada buku Mission at The Crossroads tulisan Th.Sumartana, seorang sastrawan dan aktivis dialog antar iman, tertulis: "In evangelization activities in Surabaya in the 1820's and the following years, the role played by a mother and her daughter, Amarentia Manuel Emde and her only child Johanna Wilhelmina Emde, must be emphasized. The famous jeweler and Dutch Protestant missionary, J.Emde, would have found it difficult to achieve results in his work if not assisted by these two women." 37 Sumartana juga menambahkan bahwa Emde agak sulit mencari istri dari perempuan Eropa karena status ekonomi dan sosialnya rendah, maka ia menikahi perempuan Jawa. Setelah menjadi Kristen, nama istrinya diganti menjadi nama Barat 
yaitu Amarentia Manuel Emde. Bagi Emde, menjadi Kristen itu berarti menjadi Barat. $^{38}$

Ketiga, dalam buku A History of Christianity in Indonesia, yang disunting oleh Jan Sihar Aritonang, seorang guru besar teologi bidang sejarah Kekristenan di STFT Jakarta, dan Karel Steenbrink, seorang profesor teologi bidang sejarah Kekristenan di Universitas Utrecht. Di sana tertulis tentang Emde demikian: “Emde, himself married to a Javanese woman, started religious services in his house. His wife was very instrumental in gathering some native people also among his following. ",39

Keempat, pada buku Magnalia Dei karya Mestoko, seorang pendeta emeritus dari GKJW, tertulis: “Dalam usahanya untuk mengabarkan Injil, J. Emde didukung istrinya. - Putrinya disuruh berkeliling kota dan membawa buku-buku bacaan untuk dijual kepada orang Belanda dan orang Indo Belanda." ${ }^{40}$ Pada bagian yang lain: “Ketika sedang berjualan sarung keris di pasar hewan Wonokromo Surabaya. Pak Dasimah mendapat sebuah buku yang diberikan oleh seorang pemudi Belanda. Sebenarnya ia tidak bisa membaca, tetapi pemudi itu mendesak pak Dasimah untuk menerima buku tersebut." ${ }^{41}$ Mestoko juga menambahkan keterangan bahwa Ny.Emde menceritakan pada anak pak Dasimah yang mengantar rumput ke rumah Emde tentang gambar yang dilihatnya mirip dengan yang ada pada buku Injil Markus yang dimiliki ayahnya. ${ }^{42}$

Kelima, pada buku Patunggilan kang Nyawiji yang ditulis oleh tim penyusun sejarah GKJW, yaitu Sulistiani, seorang pemerhati sejarah GKJW; Juli Mardiati, seorang pendeta GKJW; dan Hari Wahyono, seorang dosen sejarah pada salah satu universitas negeri di Malang, menuliskan demikian: "Pada tahun 1810/1811 ia (Emde) menikah dengan seorang perempuan Jawa bernama Amarantia Manuel (nama baptis). Bersama istrinya ia mencari dan mendorong mereka (orang-orang Eropa kelas Vrijburgers) yang "tersesat" dalam pergundikan agar meresmikan hubungan pergundikan itu menjadi hubungan perkawinan resmi yang sah." Berkaitan dengan perkawinan Emde, kembali diulang demikian: "Tanggal 4 Agustus 1981 J.Emde melakukan perkawinan dengan perempuan Jawa bernama Amarentia Manuel (nama baptis). Pada masa itu tidak mungkin bagi J.Emde mendapatkan seorang perempuan Eropa dari kalangannya, karena itu ia melakukan kawin campur. Dari perkawinannya mereka mempunyai seorang anak perempuan yang lahir pada 11 
Februari 1814 diberi nama Johanna Wilhelmina Emde. Dibaptis pada tanggal 5 Juni 1814 oleh Rev.Wiliamse." 44

Selanjutnya berkaitan dengan peran dari Amarentia dan Johanna tertulis demikian: "Dalam hal ini perlu diingat bahwa ada dua orang perempuan yang setia dan rajin bekerja, mereka adalah Amarentia Manuel, istri J.Emde dan Johanna Wilhelmina Emde anaknya. Mereka berperan sebagai penerjemah dan pembagi traktaatjes. Setelah Amarentia Manuel meninggal dunia (1846), dengan segera Emde mendaftarkan anaknya itu sebagai zendeling zuster (zendeling perempuan) untuk melayani orang Kristen Jawa di kota Surabaya. Permohonan itu diterima oleh Badan Zending NZG, sehingga Johanna Wilhelmina Emde diangkat sebagai zendeling zuster tergabung di dalam NZG. " 45 Di samping itu, dalam buku ini juga terdapat satu subbab pendek berjudul Perempuan (Amarentia Manuel) Sebagai Pembimbing ${ }^{46}$. Subbab ini menerangkan tentang bagaimana Amarentia Manuel memberi kesempatan bagi orangorang Wiyung untuk singgah di rumahnya, mengajar, dan mendorong mereka untuk mendirikan tempat kebaktian serta agar segera dibaptis.

Kelima literatur di atas menunjukkan bahwa Amarentia Manuel dan Johanna Wilhelmina Emde memiliki peran penting dalam pekabaran Injil di Jawa Timur. Namun keberadaannya tersubordinasi oleh posisi Emde yang menjadi sentral pemberitaan dalam sejarah pekabaran Injil di Jawa Timur pada tahun 1812-1848.

Catatan tentang Amarentia Manuel sangat singkat. Latar belakang kehidupannya tidak diketahui, bahkan nama aslinya pun tidak ada dalam catatan sejarah. Dari sini dapat dilihat bahwa masa lalu atau pengalaman hidup Amarentia Manuel "tidak ada". Ia "ada" setelah menikah dengan Emde dan menjadi Kristen. Pada tahun 1617 ada aturan yang melarang mantan ataupun pejabat VOC menikah dengan perempuan non Kristen. Jika ada laki-laki Eropa menikah dengan perempuan Asia, ia tidak boleh melakukan repatriasi. Sedangkan, calon pengantin perempuan diharuskan memeluk agama Kristen. Untuk itu harus dibaptis dan diberi nama Kristen sebagai tanda dilahirkan kembali. ${ }^{47}$ Itulah mengapa istri Emde setelah dibaptis namanya berganti menjadi Amarentia Manuel Emde. Amarentia Manuel tercabut dari identitasnya sebagai perempuan Jawa, namun juga tidak diakui sebagai warga Eropa, sebab para perempuan pribumi yang sudah dibaptis dan resmi menganut agama Kristen serta perkawinannya sah di mata hukum tidak otomatis memiliki hak-hak sipil 
dengan suaminya ${ }^{48}$. Apalagi ada pandangan umum bahwa pernikahan dengan perempuan pribumi berarti pengrusakan terhadap kode kolonial. Maka dari itu, sebelum tahun 1848 pernikahan antara orang Eropa Kristen dengan perempuan pribumi non Kristen dilarang. Orang Eropa yang menikah dengan perempuan pribumi dianggap berada di luar masyarakat dan kehilangan kesempatan untuk mendapatkan karier yang baik. $^{49}$

Emde pun tidak begitu saja memilih untuk menikah dengan perempuan Jawa. Sumartana mengatakan bahwa Emde sulit memperistri perempuan Eropa karena status ekonomi dan sosialnya rendah. Oleh sebab itu, ia memilih menikah dengan seorang perempuan Jawa. Meskipun pernikahan Emde dengan perempuan Jawa dapat membuatnya tidak bisa melakukan repatriasi, namun pasa sisi yang lain pernikahannya dengan Amarentia Manuel justru memberi Emde keuntungan. Seperti yang ditulis oleh Nortier, Emde menjadi orang yang terkenal, disayangi orang-orang Indo-Eropa, meski di sisi yang lain ia tidak disukai oleh orang-orang Eropa karena Emde sering mencela sikap orang Eropa yang cenderung merendahkan orang Jawa maupun orang Indo-Eropa. Ia pun rajin membantu Emde menyebarkan Injil. Ia menuliskan selebaran-selebaran dalam bahasa Jawa, memberikan pelayanan dan jamuan yang baik bagi orang yang belajar tentang Injil di rumahnya, serta mendorong orang-orang Jawa untuk dibaptis. Sedangkan Johanna, putri Emde dengan Amarentia Manuel, terlibat dalam menyebarkan traktat maupun selebaran dan kemudian menjadi zendeling perempuan dari badan zending NZG. ${ }^{50}$

Peranan Amarentia Manuel maupun Johanna Wilhelmina Emde cukup besar dalam pekabaran Injil di Jawa Timur. Namun, keberadaan mereka tetap tersubordinasi, sehingga peranan mereka dianggap tidak menonjol, kehadirannya dianggap sepantasnya dilakukan oleh perempuan dalam kehidupan rumah tangga yang mendukung laki-laki. Keberadaan perempuan hanya digunakan dan dianggap sebagai alat mencapai hasrat laki-laki dari suatu perjalanan patriarkal menjadi hubungan keluarga $^{51}$. Hal ini tidak disadari oleh Amarentia Manuel yang berlatar belakang masyarakat Jawa yang menempatkan perempuan untuk selalu manut, mrantasi, tahu diri dan mendukung suami. Dalam hal ini, kita dapat melihat adanya ketimpangan gender di mana Emde, seorang laki-laki "Barat", ditempatkan sebagai tokoh utama atau subyek dalam sejarah pekabaran Injil di Jawa Timur dengan latar belakangnya 
yang dicatat dengan jelas, sedangkan Amarentia Manuel, seorang perempuan Jawa yang bukan Kristen lalu berpindah menjadi Kristen dan tercabut dari akar identitasnya karena menikah dengan Emde, serta Johanna Wilhelmina Emde, seorang perempuan Indo Eropa, hanya ditempatkan sebagai pelengkap dalam kiprah Emde.

Kiprah Emde dalam pekabaran Injil yang didukung oleh keluarganya tidak terlepas dari cara pandang Emde terhadap Kekristenan. Ia menganggap bahwa menjadi Kristen berarti menjadi Barat. Orang Jawa yang menjadi Kristen harus melepaskan cara berpakaian dan cara hidup Jawa, berganti dengan cara berpakaian dan cara hidup Eropa. Padahal dengan melepaskan 'kejawaannya' ketika menjadi Kristen membuat orang Jawa berbeda dan teralienasi dari komunitas asalnya. Mereka sering disebut sebagai londo ireng atau londo tanpa $k u r s i^{52}$ oleh orang-orang Jawa lainnya, dan dianggap tidak lagi menjadi bagian dari komunitas asalnya. Pandangan Emde menempatkan bahwa orang Eropa Kristen adalah "Barat": lebih beradab, punya kuasa, dan patut ditiru oleh orang Jawa sebagai “Timur” yang ditaklukkan. Dengan demikian sebenarnya memunculkan dikotomi dan perbedaan kelas antara orang Eropa dan orang Jawa, orang Kristen dan bukan Kristen, orang Eropa Kristen dan Jawa bukan Kristen, orang Jawa Kristen dan orang Jawa bukan Kristen. Jadi jelaskah bahwa ketimpangan gender dianggap wajar di tengah masyarakat Jawa yang patriarki, karena diteguhkan oleh sistem kolonial yang patriarki dan memegang kendali atas kekuasaan.

\section{Analisis Gender dan Relasi Kuasa terhadap Coolen dan istrinya dalam pekabaran Injil di Jawa Timur}

Coenrad Laurens Coolen juga merupakan salah satu pionir pekabaran Injil di Jawa Timur selain Emde. Ia menjadi tokoh penting dalam sejarah GKJW. Ia membuat ajaran Kekristenan tidak asing bagi orang Jawa, khususnya di Ngoro tempat ia membuka lahan dan membangun komunitas. Misalnya ia menggubah Doa Bapa Kami, Pengakuan Iman Rasuli, dan Dasa Titah dengan menggunakan bahasa Jawa serta dijadikan tembang atau rapalan, atau mengenalkan Tuhan sebagai Juru Selamat dengan menggunakan istilah-istilah dalam budaya Jawa sehingga mudah diingat dan dipahami oleh orang-orang Jawa. Di samping itu, Coolen berusaha mempertahankan orang-orang Jawa yang masuk Kristen tidak kehilangan identitas kejawaannya. Ia 
merupakan tokoh yang karismatik, dan banyak orang-orang Jawa yang tertarik dan belajar Kekristenan dari Coolen, meski kemudian banyak juga yang belajar dari Emde, sebelum kemudian berbuah menjadi orang-orang yang merintis jemaat-jemaat Kristen di Jawa Timur. Pada catatan sejarah tentang Coolen dalam kiprahnya melakukan pekabaran Injil, ada hal yang menarik untuk diperhatikan yaitu keberadaan perempuan dalam hidup Coolen yang tampak sekilas pada beberapa literatur berikut ini.

Pertama, pada buku berjudul Tumbuh Berkembang dan Bertanggung jawab tertulis: "Di Mojoagung Coolen mengambil seorang wanita Jawa sebagai penata rumah tangga. Wanita ini kemudian diperistrikannya. Dari perkawinan ini ia memperoleh 6 orang anak"53

Kedua, pada buku A History of Christianity in Indonesia, dituliskan demikian: "At the beginning of his spiritual career in the 1810s he (Coolen) divorced his European wife and took a Javanese wife on his estate of Ngoro. After the five children with his first wife, he had six children with one or even two Javanese wives in Ngoro. ",54

Ketiga, pada buku Magnalia Dei karya, tertulis demikian:

"Di sana (Surabaya) Coolen menikah dengan perempuan asal Pekalongan, Surabaya. Dari istri pertama ia mempunyai tiga orang anak. Setelah dinas militernya sudah selesai ia pindah ke Wirosobo (Mojoagung) dan bekerja sebagai sinder blandong di dinas kehutanan. Sedangkan istrinya tidak krasan tinggal di pedalaman maka tidak ikut dan tinggal di Surabaya sehingga C.L.Coolen sendirian saja dan ditemani oleh seorang pembantu rumah tangga yang namanya Sadijah. Akhirnya, Sadijah dijadikan istri dengan cara yang tidak sah oleh C.L.Coolen, dan mempunya enam orang anak. "55

Keempat, pada buku Patunggilan Kang Nyawiji ditulis demikian:

“C.L.Coolen merasa tidak nyaman berada di tengah-tengah lingkungan kelompok Orang Saleh Surabaya (OSS). Ia ingin menjadi orang Kristen yang bebas tidak dikekang oleh aturan kesalehan. Yang dimaksud dengan kebebasan sikap hidup C.L.Coolen adalah: ia beristri lebih dari satu. Yang dalam budaya Jawa dipahami sebagai seorang selir. Hal itu 
baru diketahui oleh kelompok OSS sekitar tahun 1826-1827 bahwa, selain istrinya yang sah menurut hukum Eropa (Maria Christina Carolina Herweg), C.L.Coolen juga memiliki istri (selir) orang Jawa benama Sadijah. Diduga perkawinannya secara hukum Eropa itu dilakukan semata-mata untuk memenuhi syarat pengakuan kepemilkan hak sebagai warga Eropa. Selama dia di kelompok OSS (1814-1826) ia tidak pernah menceritakan jika telah mempunyai istri Jawa." ${ }^{, 56}$

Coolen lahir dari pasangan campuran, ayahnya adalah pegawai VOC berdarah Rusia, ibunya adalah seorang perempuan Jawa keturunan ningrat dari Kerajaan Mataram. Jika melihat peraturan VOC, kemungkinan besar ayah Coolen tidak dapat mendampingi dalam tumbuh kembang Coolen. Pengasuhan dan pendidikan Coolen hingga remaja dilakukan oleh ibunya dalam lingkungan budaya Jawa. Hal tersebut menjadi salah satu faktor yang membentuk Coolen begitu lekat dengan budaya Jawa. Setelah dewasa, Coolen harus dibaptis dan bergabung dengan Gereja Protestan untuk mendapatkan hak sipil Eropa dan dapat tinggal di kota Benteng, yaitu tempat masyarakat koloni VOC tinggal. Ia tinggal di kampung Kalongan Surabaya, berkeluarga, kawin sah sesuai dengan hukum Eropa dengan Maria Christina Carolina Herweg, dan memiliki lima anak. ${ }^{57}$

Pada beberapa literatur yang ada di atas, tampak ada beberapa keterangan yang berbeda terkait istri Coolen yang pertama. Mestoko menyebut Coolen memperistri perempuan asal Pekalongan-Surabaya, dan memiliki tiga orang anak. Dalam buku yang disunting oleh Aritonang dan Steenbrink hanya dikatakan bahwa Coolen bercerai dari seorang perempuan Eropa. Baru dalam buku Patunggilan kang Nyawiji ditulis nama perempuan Eropa yang menjadi istri Coolen, yaitu Maria Christina Carolina Herweg. Ini menegaskan bahwa nama seorang perempuan sebagai bagian dari identitasnya tidaklah dianggap penting dalam sejarah yang dibentuk pada masa kolonial, bahkan meski perempuan tersebut adalah seorang Eropa.

Pernikahan Coolen dengan Maria Herweg juga tidak lepas dari kepentingan politis. Kala itu, orang-orang Indo-Eropa, lebih mengutamakan pasangan berdarah Eropa murni karena dianggap dapat menaikkan status sosial ${ }^{58}$. Jadi dengan menikahi Maria Herweg, status sosial Coolen yang berasal dari keturunan Indo-Eropa naik. Meski demikian, status sosial Coolen kembali berubah ketika Hindia-Belanda dikuasai 
oleh Inggris, ia yang sedang bergabung dalam kemiliteran memilih untuk keluar dari tugas militernya dan beralih menjadi kontraktan dan penjual jasa, khususnya dalam bidang pengangkutan barang hasil pertanian dan calo hewan ternak. Berubahnya pekerjaan Coolen membuat status sosial yang semula adalah regering dienaren turun pada strata sosial terendah yaitu vrijburger, atau orang Eropa yang menjadi warga bebas. ${ }^{59}$ Lalu ia memilih pindah dari Surabaya dan tinggal di Mojoagung sambil melakukan pekerjaannya dan menjadi pengawas hutan. Ia tinggal dengan pembantunya, seorang perempuan Jawa bernama Sadijah, yang kemudian dijadikannya istri dan memiliki enam orang anak ${ }^{60}$. Keputusan Coolen untuk menikah dengan Sadijah setelah bercerai dari Maria Herweg, membuat Gereja Protestan Surabaya, tempat Coolen bergabung sebelumnya, menganggapnya sebagai pembangkangan terhadap disiplin gereja.

Perkawinan antara laki-laki Eropa atau Indo-Eropa dengan perempuan Jawa yang menjadi pembantu rumah tangganya disebut pergundikan. Pergundikan merupakan aib dalam kehidupan masyarakat pribumi, karena dianggap mengkhianati agama dengan hidup bersama orang Kristen, sehingga dikucilkan dari masyarakat ${ }^{61}$. Pada beberapa literatur di atas, keberadaan Sadijah tidak pernah disebut lebih dalam dari sebatas pembantu rumah tangga yang diperistri oleh Coolen. Apalagi Sadijah juga belum menjadi Kristen secara sah, dalam arti mendapatkan baptisan, karena Gereja Protestan Surabaya menolak membaptiskan Sadijah dan anak-anaknya ${ }^{62}$. Keberadaan Sadijah ditolak oleh komunitas Kristen orang-orang Eropa, juga tersisih dari lingkungan asalnya karena menjadi gundik.

Tindakan Coolen menolak baptisan bagi orang Jawa yang menjadi Kristen tidak terjadi begitu saja. Dulu Coolen dibaptis bukan semata-mata berkenaan dengan iman dan kebutuhan rohani, namun juga ada kepentingan politis yaitu agar mendapat pengakuan sebagai warga negara Eropa. Pengakuan itu tidak berlaku bagi orang Jawa. Dengan demikian, Coolen melihat bahwa baptisan adalah cara orang Eropa memperdaya bangsa jajahannya, karena meski telah dibaptis, orang-orang di Jawa harus tetap mematuhi orang Eropa yang dapat melakukan apa saja ${ }^{63}$. Di samping itu, ketika Coolen berniat meminta sakramen baptis bagi Sadijah dan anak-anaknya dari Gereja Protestan Surabaya, mereka ditolak. Hal-hal tersebut semakin meneguhkan Coolen untuk menyatakan bahwa orang Jawa yang masuk Kristen tidak perlu dibaptis 
agar tetap "Jawa" tanpa perlu menjadi "Barat", karena baptisan dipandang sebagai suatu tradisi Eropa. Itulah mengapa baptisan tidak perlu dilakukan bagi orang-orang Jawa. Apalagi pada masa itu muncul anggapan bahwa baptisan hanyalah penanda status baru dan memunculkan kesalahpahaman di tengah masyarakat Jawa.

Pada sisi yang lain, juga perlu diingat bahwa Coolen adalah juga seorang "Barat", keturunan Indo Eropa yang telah mendapat pengakuan sebagai warga negara Eropa, dan ia seorang tuan tanah. Ia membuka hutan, menjadikannya lahan-lahan pertanian. Suasana khas feodalisme tercermin pada Coolen. Ia menerima siapa saja untuk menetap dan mengolah lahan di sana sambil mengenalkan Injil bagi mereka. Coolen juga memiliki sikap otoriter dan memperlakukan orang Jawa sebagai bawahannya ${ }^{64}$, sedangkan orang-orang Jawa yang menetap di sana hidupnya bergantung pada Coolen. Cukup masuk akal bila orang Jawa yang menjadi Kristen dianggapnya tidak perlu dibaptis dan membuat mereka tetap "Jawa", tetap "Timur", supaya orang Jawa tidak perlu menjadi "Barat". Hal ini pernah dikhawatirkan oleh Daendels yang memandang baptisan dan mengganti nama dapat menimbulkan bahaya karena orang Jawa akan mencoba mendapatkan kewarganegaraan Belanda dengan segala hak istimewanya, termasuk salah satunya adalah terbebas dari kerja paksa ${ }^{65}$. Agama awalnya digunakan untuk penanda perbedaan di wilayah kolonial. Namun, ketika orang-orang pribumi berpindah agama menjadi Kristen, agama menjadi kurang berguna sebagai alat pembeda. Kemudian warna kulit menjadi lebih penting digunakan sebagai pembeda kelas. ${ }^{66}$ Oleh karena itu, orang Jawa dipertahankan kejawaannya, dibuat tetap “Timur”, supaya Coolen tetap memiliki kuasa atas mereka.

\section{KESIMPULAN}

Tahun 1812-1848 dapat dikatakan sebagai masa awal penanaman Injil di Jawa Timur. Periode tersebut dimulai dengan Johannes Emde dan Amarentia Manuel, istrinya, serta Johanna Wilhelmina Emde, anaknya, mewartakan Injil di daerah Surabaya. Kemudian sekitar tahun 1827 Coenrad Laurens Coolen bersama Sadijah, istrinya, anak-anaknya membuka hutan di Ngoro. Coolen menerima siapa saja tinggal di sana, mengolah tanah, dan mewartakan Injil pada orang-orang yang datang dan menetap di sana. Sekitar tahun 1844 Singotaruno, Ditotaruno, Tosari, dan Kunto yang belajar mengenai Kristus pada Coolen di Ngoro dibaptis oleh Pdt. Van Rossem di 
Surabaya, ${ }^{67}$ meski ketika kembali ke Ngoro mereka diusir oleh Coolen. Namun hal tersebut kemudian diiukuti oleh rekan-rekan lainnya.langkah untuk meminta dibaptis Dengan kata lain, periode 1812-1848 menjadi titik pijak awal berkembangnya Kekristenan di Jawa Timur, khususnya di GKJW. Setelah melalui pembahasan di atas, ternyata sejarah pekabaran Injil di Jawa Timur pada tahun 1812-1848 terdapat ketimpangan gender dan diteguhkan oleh relasi kuasa yang ada. Subyek historis diberikan pada laki-laki "Barat" dan para perempuan adalah perwujudan "Timur" yang ditempatkan sebagai pelengkap, bahkan dituliskan semata-mata sebagai informasi untuk menerangkan keberadaan, peran, dan kiprah laki-laki. Keberadaan Amarentia Manuel, Johanna Wilhelmina Emde, Maria Christina Carolina Herweg, dan Sadijah adalah bukti betapa sulitnya para perempuan memiliki identitas diri, kehidupannya sendiri, dan pengakuan atas eksistensinya, apalagi mengartikulasikan pengalaman hidupnya di bawah kuasa kolonial nan partriakal. Mereka tidak mendapat tempat yang layak, baik dalam keluarga, gereja, maupun di tengah masyarakat.

Penelitian ini menunjukkan bahwa dalam suatu periode tertentu dari sejarah pekabaran Injil dengan contohnya di Jawa Timur membuktikan bahwa terjadi ketimpangan kelas, ras, gender, dan kekuasaan yang saling berkaitan. Ini membawa kesadaran bahwa ketidakadilan gender dan relasi kuasa dalam masyarakat atau komunitas yang menekan bisa terjadi dalam sejarah Kekristenan di mana saja dan pada periode waktu kapan saja. Kesadaran ini diperlukan dalam membaca sejarah. Dengan demikian, perkembangan sejarah Kekristenan, baik itu di Jawa Timur maupun di mana saja, bisa mendapatkan beragam nilai-nilai dan pandangan, sebagaimana beragam pula pengalaman perempuan dan laki-laki, para subyek historis. Jadi, lensa penelitian ini dapat digunakan dan dikembangkan untuk membantu melihat sejarah Kekristenan di wilayah maupun gereja-gereja lain, supaya sejarah dapat dibaca dengan lebih utuh, serta dapat memberi makna lebih beragam dari suara-suara yang sebelumnya tidak terdengar. 


\section{Endnotes:}

${ }^{1}$ Sulistiani, Juli Mardiati, dan Hari Wahyono, Patunggilan Kang Nyawiji: Jejak Protestanisme di Pedalaman Jawa Timur, Buku 1 (Jakarta: BPK Gunung Mulia, 2021). 37-8.

${ }^{2}$ J. D Wolterbeek, Babad Zending di Pulau Jawa (Yogyakarta: Taman Pustaka Kristen, 1995). 5.

${ }^{3}$ Merry Wiesner-Hanks, Gender in History: Global Perspectives, 2 ed. (New Jersey: WileyBlackwell, 2011). 125.

4 Emy Susanti, "Perempuan, Relasi Kuasa, dan Sosiologi Gender," Jawa Pos.com, 2017, https://www.jawapos.com/opini/01/07/2017/perempuan-relasi-kuasa-dan-sosiologi-gender/.

5 Danik Fujiati, "Relasi Gender Dalam Institusi Keluarga Ddalam Pandangan Teori Sosial dan Feminis," MUWÂZÂH 6, no. 1 (2014), https://media.neliti.com/media/publications/153130-ID-relasigender-dalam-institusi-keluarga-d.pdf.

${ }^{6}$ Tanti Hermawati, "Budaya Jawa dan Kesetaraan Gender,” Jurnal Komunikasi Massa 1, no. 1 (2007): 18-24, https://doi.org/10.1111/j.1523-1739.2010.01600.x.

${ }^{7}$ Kwok Pui-Lan, "Historical, Dialogical , and Diasporic Imagination in Feminist Studies of Religion," Journal of the European Society of Women in Theological Research 10 (2002): 57-80, https://doi.org/10.2143/eswtr.10.0.583308.

${ }^{8}$ Pui-Lan.

${ }^{9}$ Kwok Pui-Lan, Introducing Asian Feminist Theology (Sheffield: Sheffield Academic Press, 2000). 18.

${ }^{10}$ Elisabeth Schussler Fiorenza, In Memory of Her: A Feminist Theological Reconstruction of Christian Origins, vol. 10 (New York: The Crossroad Publishing Company, 1994), https://doi.org/10.2307/3260702. xxii.

${ }^{11}$ Pui-Lan, Introducing Asian Feminist Theology. 19.

${ }^{12}$ Edward W. Said, Orientalisme: Menggugat Hegemoni Barat dan Mendudukkan Timur sebagai Subjek, ed. oleh Saifuddin Zuhri Qudsy (Yogyakarta: Pustaka Pelajar, 2016). 109.

${ }^{13}$ Said. 67-8.

${ }^{14}$ Said. 100.

${ }^{15}$ Said. 312-4.

${ }^{16}$ Pui-Lan, Introducing Asian Feminist Theology. 21-2.

${ }^{17}$ Kwok Pui-Lan, Postcolonial Imagination \& Feminist Theology (Louisville: Westminster John Knox Press, 2005). 3.

${ }^{18}$ Pui-Lan. 9.

${ }^{19}$ Pui-Lan. 34.

${ }^{20}$ Pui-Lan. 32.

${ }^{21}$ Philip van Akkeren, Dewi Sri dan Kristus: Sebuah Kajian Tentang Gereja Pribumi di Jawa Timur, ed. oleh B.A. Abednego (Jakarta: BPK Gunung Mulia, 1995). 68-69.

${ }^{22}$ C.W. Nortier, Tumbuh, Dewasa, Bertanggung jawab: Suatu studi mengenai pertumbuhan Greja Kristen Jawi Wetan menuju ke kedewasaan dan kemerdekaan \pm 1835-1935 (Jakarta: BPK Gunung Mulia, 1981). 22-4.

${ }^{23}$ Th. Sumartana, Mission At The Crossroads: Indigenous Churches, European Missionaries, Islamic Association and Socio-Religious Change in Java 1812-1936 (Jakarta: BPK Gunung Mulia, 1993). 17.

${ }^{24}$ Ismanoe Mestoko, Magnalia Dei: Karya Allah yang Agung - Sejarah Greja Kristen Jawi Wetan (Yogyakarta: Kanisius, 2019). 43.

${ }^{25}$ Mestoko. 44.

${ }^{26}$ Ibid, 54-5.

${ }^{27}$ Nortier, Tumbuh, Dewasa, Bertanggung jawab: Suatu studi mengenai pertumbuhan Greja Kristen Jawi Wetan menuju ke kedewasaan dan kemerdekaan \pm 1835-1935. 24

${ }^{28}$ Nortier. 5-17.

${ }^{29}$ Akkeren, Dewi Sri dan Kristus: Sebuah Kajian Tentang Gereja Pribumi di Jawa Timur. 69.

${ }^{30}$ Ada perbedaan catatan sejarah terkait hal ini. Mestoko menuliskan Coolen menikah dengan perempuan asal Pekalongan, Surabaya dan memiliki tiga orang anak; dalam catatan Aritonang tertulis, Coolen menikah dengan perempuan Eropa; dan pada Buku 1 sejarah GKJW menerangkan Coolen menikah dengan perempuan Eropa bernama Maria Christina Carolina Herweg, dan menikahi perempuan Jawa bernama Sadijah. 
${ }^{31}$ Nortier, Tumbuh, Dewasa, Bertanggung jawab: Suatu studi mengenai pertumbuhan Greja Kristen Jawi Wetan menuju ke kedewasaan dan kemerdekaan \pm 1835-1935. 20.

${ }^{32}$ Nortier. 11-21

${ }^{33}$ Mestoko, Magnalia Dei: Karya Allah yang Agung - Sejarah Greja Kristen Jawi Wetan. 27, 30.

34 Sulistiani, Mardiati, dan Wahyono, Patunggilan Kang Nyawiji: Jejak Protestanisme di Pedalaman Jawa Timur. 84.

${ }^{35}$ Nortier, Tumbuh, Dewasa, Bertanggung jawab: Suatu studi mengenai pertumbuhan Greja Kristen Jawi Wetan menuju ke kedewasaan dan kemerdekaan \pm 1835-1935. Xi.

${ }^{36}$ Nortier. 23.

37 Sumartana, Mission At The Crossroads: Indigenous Churches, European Missionaries, Islamic Association and Socio-Religious Change in Java 1812-1936. 17.

${ }^{38}$ Sumartana.

39 Jan Sihar Aritonang dan Karel Steenbrink, A History of Christianity in Indonesia, vol. 35 (Boston: Brill, 2008), https://doi.org/10.1163/ej.9789004170261.i-1004. 713.

${ }^{40}$ Mestoko, Magnalia Dei: Karya Allah yang Agung - Sejarah Greja Kristen Jawi Wetan. 42-3.

${ }^{41}$ Mestoko. 44.

${ }^{42}$ Mestoko. 55

43 Sulistiani, Mardiati, dan Wahyono, Patunggilan Kang Nyawiji: Jejak Protestanisme di Pedalaman Jawa Timur. 84.

${ }^{44}$ Sulistiani, Mardiati, dan Wahyono. 104.

${ }^{45}$ Sulistiani, Mardiati, dan Wahyono. 150-1.

${ }^{46}$ Sulistiani, Mardiati, dan Wahyono. 167-8.

${ }^{47}$ Reggie Baay, Nyai \& Pergundikan di Hindia Belanda, ed. oleh Dahlia Isnaini dan Rahmat Edi Sutanto (Depok: Komunitas Bambu, 2017). 11.

48 Baay. 36.

${ }^{49}$ Baay. 73-5.

50 Sulistiani, Mardiati, dan Wahyono, Patunggilan Kang Nyawiji: Jejak Protestanisme di Pedalaman Jawa Timur. 167-8.

51 Simone De Beauvoir, Second Sex: Fakta dan Mitos, ed. oleh Toni Setiawan dan Nuraini Juliastuti (Yogyakarta: Narasi, 2019). 143.

${ }^{52}$ Aritonang dan Steenbrink, A History of Christianity in Indonesia. 713.

${ }^{53}$ Nortier, Tumbuh, Dewasa, Bertanggung jawab: Suatu studi mengenai pertumbuhan Greja

Kristen Jawi Wetan menuju ke kedewasaan dan kemerdekaan \pm 1835-1935. 6.

${ }^{54}$ Aritonang dan Steenbrink, A History of Christianity in Indonesia. 714.

${ }^{55}$ Mestoko, Magnalia Dei: Karya Allah yang Agung - Sejarah Greja Kristen Jawi Wetan. 20

56 Sulistiani, Mardiati, dan Wahyono, Patunggilan Kang Nyawiji: Jejak Protestanisme di Pedalaman Jawa Timur. 108-9.

${ }^{57}$ Sulistiani, Mardiati, dan Wahyono. 110-1.

${ }^{58}$ Baay, Nyai \& Pergundikan di Hindia Belanda. 53.

59 Sulistiani, Mardiati, dan Wahyono, Patunggilan Kang Nyawiji: Jejak Protestanisme di Pedalaman Jawa Timur. 112.

${ }^{60}$ Dalam buku yang disunting oleh Aritonang dan Steenbrink tertulis bahwa Coolen memiliki enam anak dari satu atau dua istri Jawa di Ngoro.

${ }^{61}$ Baay, Nyai \& Pergundikan di Hindia Belanda. 55.

62 Sulistiani, Mardiati, dan Wahyono, Patunggilan Kang Nyawiji: Jejak Protestanisme di Pedalaman Jawa Timur. 173.

${ }^{63}$ Sulistiani, Mardiati, dan Wahyono. 172.

${ }^{64}$ Mestoko, Magnalia Dei: Karya Allah yang Agung - Sejarah Greja Kristen Jawi Wetan. 55.

${ }^{65}$ Akkeren, Dewi Sri dan Kristus: Sebuah Kajian Tentang Gereja Pribumi di Jawa Timur. 102.

${ }^{66}$ Wiesner-Hanks, Gender in History: Global Perspectives. 40.

${ }^{67}$ Wolterbeek, Babad Zending di Pulau Jawa. 19-20. 


\section{DAFTAR PUSTAKA}

Akkeren, Philip van. Dewi Sri dan Kristus: Sebuah Kajian Tentang Gereja Pribumi di Jawa Timur. Diedit oleh B.A. Abednego. Jakarta: BPK Gunung Mulia, 1995.

Aritonang, Jan Sihar, dan Karel Steenbrink. A History of Christianity in Indonesia.

Vol. 35. Boston: Brill, 2008. https://doi.org/10.1163/ej.9789004170261.i1004.

Baay, Reggie. Nyai \& Pergundikan di Hindia Belanda. Diedit oleh Dahlia Isnaini dan Rahmat Edi Sutanto. Depok: Komunitas Bambu, 2017.

Beauvoir, Simone De. Second Sex: Fakta dan Mitos. Diedit oleh Toni Setiawan dan Nuraini Juliastuti. Yogyakarta: Narasi, 2019.

Fiorenza, Elisabeth Schussler. In Memory of Her: A Feminist Theological Reconstruction of Christian Origins. Vol. 10. New York: The Crossroad Publishing Company, 1994. https://doi.org/10.2307/3260702.

Fujiati, Danik. "Relasi Gender Dalam Institusi Keluarga Ddalam Pandangan Teori Sosial dan Feminis." MUWÂZÂH 6, no. 1 (2014). https://media.neliti.com/media/publications/153130-ID-relasi-genderdalam-institusi-keluarga-d.pdf.

Hermawati, Tanti. "Budaya Jawa dan Kesetaraan Gender." Jurnal Komunikasi Massa 1, no. 1 (2007): 18-24. https://doi.org/10.1111/j.1523-1739.2010.01600.x.

Mestoko, Ismanoe. Magnalia Dei: Karya Allah yang Agung - Sejarah Greja Kristen Jawi Wetan. Yogyakarta: Kanisius, 2019.

Nortier, C.W. Tumbuh, Dewasa, Bertanggung jawab: Suatu studi mengenai pertumbuhan Greja Kristen Jawi Wetan menuju ke kedewasaan dan kemerdekaan \pm 1835-1935. Jakarta: BPK Gunung Mulia, 1981.

Pui-Lan, Kwok. "Historical, Dialogical, and Diasporic Imagination in Feminist Studies of Religion." Journal of the European Society of Women in $\begin{array}{llll}\text { Theological } & \text { Research } & 10 & \text { (2002): }\end{array}$ https://doi.org/10.2143/eswtr.10.0.583308.

- Introducing Asian Feminist Theology. Sheffield: Sheffield Academic Press, 2000. 
. Postcolonial Imagination \& Feminist Theology. Louisville: Westminster John Knox Press, 2005.

Said, Edward W. Orientalisme: Menggugat Hegemoni Barat dan Mendudukkan Timur sebagai Subjek. Diedit oleh Saifuddin Zuhri Qudsy. Yogyakarta: Pustaka Pelajar, 2016.

Sulistiani, Juli Mardiati, dan Hari Wahyono. Patunggilan Kang Nyawiji: Jejak Protestanisme di Pedalaman Jawa Timur. Buku 1. Jakarta: BPK Gunung Mulia, 2021.

Sumartana, Th. Mission At The Crossroads: Indigenous Churches, European Missionaries, Islamic Association and Socio-Religious Change in Java 1812-1936. Jakarta: BPK Gunung Mulia, 1993.

Susanti, Emy. "Perempuan, Relasi Kuasa, dan Sosiologi Gender." Jawa Pos.com, 2017. https://www.jawapos.com/opini/01/07/2017/perempuan-relasikuasa-dan-sosiologi-gender/.

Wiesner-Hanks, Merry. Gender in History: Global Perspectives. 2 ed. New Jersey: Wiley-Blackwell, 2011.

Wolterbeek, J.D. Babad Zending di Pulau Jawa. Yogyakarta: Taman Pustaka Kristen, 1995. 